\title{
Investigating the Language Learning Strategies of Students in the Foundation Program of United Arab Emirates University
}

\author{
Sadiq Abdulwahed Ahmed Ismail ${ }^{1} \&$ Ahmad Z. Al Khatib ${ }^{1}$ \\ ${ }^{1}$ College of Education, United Arab Emirates University, Al-Ain, United Arab Emirates \\ Correspondence: Sadiq Abdulwahed Ahmed Ismail, College of Education, United Arab Emirates University, P. \\ O. Box 15551, Al-Ain, United Arab Emirates. E-mail: ism232@yahoo.com
}

\author{
Received: July 22, 2013 Accepted: August 19, 2013 Online Published: August 29, 2013 \\ doi:10.5539/ies.v6n9p135 URL: http://dx.doi.org/10.5539/ies.v6n9p135
}

\begin{abstract}
Recently, language learning strategies have gained a lot of importance in different parts of the world, including the United Arab Emirates (UAE). Successful foreign or second language learning attempts are viewed in the light of using appropriate and effective language learning strategies. This study investigated the patterns of language learning strategies (LLS) used by 190 male and female students in the Foundation Program of the United Arab Emirates University (UAEU). It also explored the effects of language proficiency level and gender on the use of these strategies. An Arabic translated version of the Oxford's (1990) Strategy Inventory for Language Learning (SILL) was used for collecting the data. The results demonstrate that these learners were overall medium strategy users. Metacognitive strategies were the most frequently used among the six strategies followed by social strategies, compensation strategies, affective strategies, cognitive strategies and memory strategies respectively. Proficiency level and gender had no significant effect on the overall strategy use nor on the use of each individual strategy. The findings of this study provide some implications for classroom instruction, curriculum design and teacher training. The study ended with some recommendations to direct future studies.
\end{abstract}

Keywords: English language, learning strategies, gender, proficiency levels, skills

\section{Introduction}

Today, English language is seen very important for Emirati students' personal and professional life. English is needed to facilitate communication as the United Arab Emirates is hosting a huge expatriate population from diverse language and cultural backgrounds. In the UAE today, children need to start learning English in KG classes. In 2007 the Ministry of Higher Education and Scientific Research introduced the Common Educational Proficiency Assessment (CEPA), an exam of English proficiency, in order to identify those students who need to be placed in foundation programs to improve their English to enable them to pursue academic studies in their colleges (CEPA, 2011). Foundation programs consume a considerable portion of the tertiary education budget. The UAEU, for example, spends more than a third of its budget on the University General Requirements Unit (UGRU) (Farah, \& Ridge, 2009). Instruction at UGRU is mostly designed to help students develop their different language skills and meet the university requirements of scoring 5 or above in the IELTS Exam. It is expected that effective language learning strategy training can reduce the time students spend in the foundation program which may in turn helps in reducing the budget.

Although there is a considerable amount of research conducted in other parts of the world about learning strategies, the gulf region share of this research is very limited. The language learning strategy patterns of English language learners in the Arab world is still largely under investigation and the outcomes of similar studies conducted with other ethnic groups in other regions can't be fully generalized in the Gulf region, including the UAE (Riazi, 2007). Only limited number of studies examined the use of learning strategies by students in the Arab world (Abu Shmais, 2003; Al-Shaboul, Asassfeh, \& Al Shboul, 2010; McMullen, 2009) and a few studies investigated the use of LLS in some gulf countries in general and the UAE context in particular (McMullen, 2009; Riazi, 2007; Radwan, 2011). Gender is also found to be an important variable that may impact language learning. However, very few studies were conducted to explore the impact of gender factor on language learning (Radwan, 2011; Rahimi \& Riazi, 2005; Riazi, 2007; Yang, 2010). 
Despite the essential role of English in UAE's schools, many students at UAEU do not usually perform very well in the CEPA Exam. This might result in admitting them into the University General Requirements Unit to give them more chance to improve their English before they start taking courses in their colleges within the university (CEPA, 2011). It is expected that effective language learning strategy training can reduce the time and money spent in foundation programs. Thus, an investigation of how students in the UAE context employ these strategies is very beneficial. Findings from this research can provide useful pedagogical information to curriculum designers, teachers and students. Curriculum designers can use these findings in developing materials and textbooks for English language instruction. English language instructors can also benefit from learning about the strategies used by successful and unsuccessful learners in designing lesson plans, deciding on appropriate teaching procedures and/or strategies and catering for students with diverse skills, abilities and learning styles.

\section{Literature Review}

Language learning strategies can be defined as "the conscious or semi-conscious thoughts and behaviors used by learners with the explicit goal of improving their knowledge and understanding of a target language" (Cohen, 2003, p. 280). LLS have attracted the attention of a number of researchers in the areas of second language acquisition (McMullen, 2009; Chamot, Barnhardt, El-Dinary, \& Robbins, 1999; Riazi, 2007; Radwan, 2011; Ehrman \& Oxford, 1990; Abu Shmais, 2003; Rahimi \& Riazi, 2005; Littlewood, 2001; Dornyei, 1990). Researchers concluded that not all learners learn in much the same way as the strategies they use might be different. These differences and the reasons affecting them have also attracted many scholars to attempt to identify the most and the least used strategies in order to improve students' language learning (Al-Shaboul, Asassfeh, \& Al Shboul, 2010). However, There is no agreement among rearchers regarding this issue (Griffiths \& Parr, 2001).

Relevant studies highlighted some factors that may influence language learning strategy patterns used by language learners such as gender, learning styles, cultural backgrounds, attitudes and motivation (Chamot, Barnhardt, El-Dinary, \& Robbins, 1999; Radwan, 2011; Riazi, 2007; Ehrman \& Oxford, 1990; Abu Shmais, 2003; Rahimi \& Riazi, 2005; Littlewood, 2001; Dornyei, 1990).

In a recent study, Radwan (2011) investigated the use of language learning strategies of 128 students majoring in English at a university in Oman and the relationship between gender and English proficiency. Results showed a medium range in the overall use of strategy. The students used metacognitive strategies significantly more than any other strategies and memory strategies fell at the bottom of students' preference scale. There were no significant differences found between males and females in the overall use of strategies. Male students used more social strategies than female students. Moreover, the relationship between strategy use and language proficiency showed that language proficiency had a significant effect on the overall uses of strategies.

Similarly, McMullen (2009) investigated language learning strategy use of 165 male and female Saudi EFL students in three universities in Saudi Arabia. The findings showed overall strategy use of both groups fell within a medium range. The results showed that gender and academic major did not have any statistical significant effect on the use of LLS among Saudi EFL students. The results also demonstrated that Saudi EFL students as a whole favored three strategies (social, metacognitive, and compensation) but neglected three others (cognitive, memory, and affective). The results also indicated that female students used slightly more LLS than male students.

Riazi (2007) investigated the patterns of English language learning strategy use of 120 female Arabic-speaking students majoring in English at a university in Qatar using Oxford's (1990) SILL. The results showed that learners used learning strategies with high to medium frequency. The highest rank was recorded for metacognitive strategies while the lowest rank was recorded for compensation strategies. In addition, the results indicated that freshmen students reported the highest rate of strategy use.

In another region of the Arab World, Al-Shaboul, Asassfeh, \& Al Shboul (2010) used Oxford's (1990) SILL to explore learning strategies use of 111 English-major students at a university in Jordan. The mean value for students' use of the entire learning strategies was considerably high. Similar to previous studies (Radwan, 2011; McMullen, 2009), metacognitive strategies were ranked the highest frequently used strategies, whereas memory strategies were ranked the least frequently used ones. Results also highlighted that proficiency level is responsible for the more frequent use of the strategies. The study also revealed that female students often use strategies more frequently than males.

Within a similar context, Khalil (2005) investigated language learning strategy use of 194 high school students and 184 university students in Palestine using Oxford's (1990) SILL. The findings revealed that overall strategy use of both groups fell within the medium range of strategy use. Metacognitive and social strategies were ranked 
the highest, whereas memory and affective strategies were ranked the lowest. Female students reported significantly higher frequency strategy use than male students.

Another study within the same line and context (Abu Shmais, 2003) examined the frequency of English language learning strategy use of 99 male and female Arabic-speaking university students in Palestine in relation to gender and proficiency variables. The results showed that the participants were medium strategy users in general. The highest rank of strategy use was recorded for Metacognitive strategies while the lowest was recorded for compensation strategies. Gender and proficiency were found to have no impact on the use of strategies.

Most of the aforementioned research reported that most Arab English language learners are medium language learning strategy users (Abu Shmais, 2003; Gerami \& Baighlou, 2011; Khalil, 2005; McMullen, 2009; Radwan, 2011). Learners were found to place the use of Metacognitive strategies at the top of the scale while affective and Memory strategies came at the bottom of the scale (Gerami \& Baighlou, 2011; Khalil, 2005; McMullen, 2009).

In conclusion, researchers conducting different studies came up with various results about the effects of proficiency level and gender on the use of LLS. Some researchers indicated no significant effects of gender on LLS (McMullen, 2009; Radwan, 2011), while others reported the existence of such influence (Abu Shmais, 2003; Gerami \& Baighlou, 2011; Khalil, 2005). The same might be true about the effects of proficiency levels on the use of the LLS. Radwan (2011) and Khalil (2005), for example, reported significant effects of proficiency level on LLS while other researchers, such as Riazi (2007) found no significant correlation between LLS and proficiency levels.

The above review of the relevant literature guided the researchers to formulate the objectives of the study. In brief, the first main objective of this study is to shed light on students' choices and uses of language learning strategies. Another objective is to identify the least and most used strategies by UGRU's students. One more objective is to identify the relationship between the uses of language learning strategies and language proficiency levels and gender. In the light of those major objectives, the present study is hoping to make valuable contributions to the existing literature in the area of language learning strategies. It will also offer guidance to all concerned parties at different levels, such as policy and/or decision makers, curriculum designers, materials developers, classroom instructors, etc.

\section{Research Questions}

This study attempted to answer the following three research questions:

1. What are the general patterns of English language learning strategies used by UGRU's students at the UAEU?

2. What is the relationship between the use of English language learning strategies and the language proficiency of UGRU's students at level one, level two and level three?

3. What is the relationship between UGRU male and female students' uses of English language learning strategies?

\section{Methodology}

\subsection{Participants}

This study was conducted with 131 female and 59 male university students. Almost $95 \%$ of the total number of participants (190) was between 18 and 21 years old. All participants were studying English at different levels (level 1, level 2 \& level 3) in the University General Requirements Unit during the time of conducting the study. The score in the CEPA exam (an entrance exam for national universities and colleges) is used as a benchmark for acceptance in the UGRU's program. The distribution of students on the three levels (English level 1, English level 2, and English level 3) of UGRU depends on their scores in the CEPA exam. Most participants began studying English at elementary school levels. They come from the different seven Emirates of the UAE. Almost half of the participants were from the Emirate of Abu Dhabi, where the university is located, and $10 \%$ were from other countries while the rest of them were from the other six emirates. When considering proficiency levels, almost $36 \%$ of them were placed at level one, $44 \%$ were placed at level two and $20 \%$ were placed at level three.

\subsection{Research Instrument}

The main instrument used in this research was an Arabic translation version of Oxford's (1990) Strategy Inventory for Language Learning. The SILL is a five point Likert-scale survey with multiple choice questions/statements that can be answered according to the following scale: 1) never or almost never true of me, 2) usually not true of me, 3) somewhat true of me, 4) usually true of me, and 5) always or almost always true of me. The taxonomy of strategies consisted of 50 statements about strategies used by language learners covering 
six broad categories of strategies: affective, social, metacognitive, memory-related, general cognitive, and compensatory. Each strategy includes a number of sub-items. In addition, Oxford (1990) developed a scale, which reflects the level of strategy usage: (1) High (3.5-5.0), (2) Medium (2.5-3.4), and (3) Low (1.0-2.4). For the purpose of this research an Arabic translation version of the SILL was used in order to allow the participants to respond accurately and to avoid any incorrect responses that might occur due to language barriers. The demographic questionnaire contained eleven items related to students' sex, age, place of residence, high school track, current level at UGRU, college major, and their English CEPA score. The background questionnaire was revised several times by the researchers in order to make it more practical.

The rationale for using this instrument is that the SILL appears to be one of the most widespread summative rating scales most often used around the world to assess the use of language learning strategies (Oxford \& Burry-Stock, 1995). The researchers adopted a committee approach to translate the SILL (Douglas \& Craig, 2007).The members of this committee included the two researchers, one of whom is a certified translator, three other experienced translators and an Arabic professional editor. The researchers revised the translation with three faculty members from the College of Education at the UAEU.

SILL's reliability was established by using Cronbach's alpha reported in different previous studies that were conducted in various countries and across different cultural groups. The value of Cronbach's alpha in those studies was found to be between .90 and .94 (Oxford, 1990; Ehrman \& Oxford, 1990; Wharton, 2000; Yang, 1996; Oxford \& Burry-Stock, 1995). To test the SILL's reliability of the Arabic translation version, the researchers also used Cronbach-alpha which was found to be .95 . This result is consistent with the findings of most studies conducted around the world. However, it shows a higher level of reliability than any other Arabic versions of the SILL used in previous studies by different researchers, such as Khalil (2005), Radwan (2011), Shmais (2003), Riazi (2007) and Al-Shaboul, Asassfeh, \& Al Shboul (2010). Table 1 demonstrates the value of the Cronbach-alpha for each of the six strategies of the translated version of the instrument.

Table 1. Reliability of the Arabic version of the SILL

\begin{tabular}{ll}
\hline Reliability Measure & Cronbach's Alpha \\
\hline Overall & .95 \\
Memory strategies & .77 \\
Cognitive strategies & .86 \\
Compensation strategies & .73 \\
Metacognitive strategies & .86 \\
Affective strategies & .76 \\
Social strategies & .83 \\
\hline
\end{tabular}

\subsection{Data Collection}

After obtaining the required permission from the UAEU's Scientific Research and Ethics Committee to conduct this research study, the researchers contacted the University's General Requirements Unit and started immediately collecting the data. It was nearly the end of the Spring Semester of the academic year 2011- 2012. A number of surveys were placed at the English Language Center (ELC) on the male campus. Many students were asked to complete the survey when they visited the Center to review for their final exams. Fifty nine surveys were completed by male students. On the female campus, 10 instructors volunteered to administer the instrument to their students. Other surveys were distributed to students in the hostels by volunteered female students. A hundred and thirty one surveys were completed by female students.

\subsection{Data Analysis}

The Statistical Package for the Social Sciences (SPSS) version 20.0 was used to obtain descriptive statistics (means, frequencies, ranges and standard deviations) from the demographic survey. The overall strategy patterns of UGRU's students (the most and least strategy items used by students) were also calculated. Data analyses for the SILL were performed using the same SPSS Program. The interpretation of the mean scores of the SILL in this research followed Oxford \& Burry-Stock (1995) scales of low for the range between 1.0 and 2.4, medium for the range between 2.5 and 3.4 and high for the range between 3.5 and 5.0. ANOVA analysis was conducted $(\mathrm{p}<0.05)$ to determine if there were any significant variations among the three levels of proficiency. T-test analysis was performed to determine if there were significant differences in the overall learning strategy use in relation to the gender variable. 


\section{Results}

Results related to the first research question (What is the general pattern of English language learning strategies used by UGRU's students at the UAEU?) demonstrate an overall medium range of strategy use among participants $(\mathrm{M}=3.02, \mathrm{SD}=.63)$. After examining the six strategies separately, this medium range of strategy use was also found to exist. Generally, metacognitive strategies were the most frequently used among the six strategies followed by social strategies, compensation strategies, affective strategies, cognitive strategies and memory strategies respectively (see table 2).

Table 2. Descriptive statistics of the SILL

\begin{tabular}{llllllll}
\hline Strategy Category & $*$ Mem & Cog & Comp & Meta & Soc & Aff & Overall \\
\hline Mean & 2.69 & 2.91 & 3.15 & 3.32 & 3.24 & 2.96 & 3.02 \\
SD & .69 & .73 & .74 & .79 & .90 & .82 & .63 \\
\hline
\end{tabular}

$*$ Mem = Memory strategy; Cog = Cognitive strategy; Comp =Compensation strategy; Meta = Metacognitive strategy; Aff = Affective strategy; Soc $=$ Social strategy.

Valid number $=190$

Findings related to the second research question (What is the relationship between the use of English language learning strategies and the language proficiency of UGRU's students at level one, level two and level three?) demonstrate a medium overall mean for all three levels: level one $(M=3.05, S D=.59)$, level two $(M=3.03, S D$ $=.67)$ and level three $(M=2.94, S D=.64)$ (see table 3$)$.

Table 3. Descriptive Statistics for the Overall Strategy Use by Proficiency Level

\begin{tabular}{llll}
\hline Proficiency Level & $\mathrm{n}$ & Mean & $\mathrm{SD}$ \\
\hline level one & 69 & 3.05 & .59 \\
level two & 83 & 3.03 & .67 \\
level three & 38 & 2.94 & .64 \\
\hline
\end{tabular}

Descriptive statistics were also conducted to show the mean of proficiency level for each strategy within the three levels. Generally, Table 4 demonstrates small differences between the mean scores of the three levels. Level three students favored the use of metacognitive strategies most $(M=3.31, S D=.71)$ and memory strategies least $(M=2.51, S D=.77)$. Level two students preferred to use metacognitive strategies most $(M=$ $3.27, S D=.81)$ and memory strategies least $(M=2.73, S D=.67)$. Level one students preferred to use metacognitive strategies most $(M=3.39, S D=.75)$ and memory strategies least $(M=2.73, S D=.66)$ (see table 4).

Table 4. Mean differences according to the three proficiency levels and strategies

\begin{tabular}{|c|c|c|c|c|c|c|c|}
\hline Proficiency & Level & Mem & Cog & Comp & Meta & Soc & Aff \\
\hline \multirow[t]{2}{*}{ Level one } & M & 2.73 & 2.88 & 3.22 & 3.39 & 3.28 & 3.04 \\
\hline & SD & 0.66 & 0.68 & 0.75 & 0.75 & 0.86 & 0.83 \\
\hline \multirow[t]{2}{*}{ Level two } & M & 2.73 & 2.94 & 3.15 & 3.27 & 3.26 & 2.94 \\
\hline & SD & 0.67 & 0.73 & 0.74 & 0.81 & 0.92 & 0.88 \\
\hline \multirow[t]{3}{*}{ Level three } & M & 2.51 & 2.89 & 3.03 & 3.31 & 3.15 & 2.87 \\
\hline & SD & 0.77 & 0.81 & 0.71 & 0.82 & 0.94 & 0.69 \\
\hline & M & 2.69 & 2.91 & 3.15 & 3.32 & 3.24 & 2.96 \\
\hline Total & SD & 0.69 & 0.73 & 0.74 & 0.79 & 0.90 & 0.82 \\
\hline
\end{tabular}

One-way ANOVA was computed to examine whether proficiency levels (English level 1, English level 2 \& English level 3) had a significant effect on both the overall strategy use and on each of the six strategies. The 
ANOVA summary indicates that proficiency levels had no significant effects on the overall strategy use nor on each of the six categories (see table 5).

Table 5. ANOVA summary of the six strategies in relation to proficiency levels

\begin{tabular}{llllll}
\hline Strategy Category & Sum of Squares & Df & Mean Square & F & Sig. \\
\hline Memory & 1.58 & 2 & .791 & 1.675 & .190 \\
Cognitive & .155 & 2 & .077 & .145 & .865 \\
Compensatory & .926 & 2 & .463 & .853 & .428 \\
Metacognitive & .549 & 2 & .275 & .438 & .646 \\
Social & .416 & 2 & .208 & .255 & .775 \\
Affective & .794 & 2 & .397 & .582 & .560 \\
Overall & .312 & 2 & .156 & .404 & .668 \\
\hline
\end{tabular}

Note. ${ }^{*} \mathrm{p}<0.05$

Results related to the third research questions (What is the relationship between UGRU male and female students' uses of English language learning strategies?) reveal an overall medium range of strategy use (males: $M=3.06, S D=.55$ and females: $M=3.00, S D=.67$ ). The differences between the mean scores of male and female students in regard to the overall strategy use were very small. Findings also indicate that both male and female learners preferred to use metacognitive strategies the most and memory strategies the least (see table 6).

Table 6. Means and SDs of the six strategies in relation to gender

\begin{tabular}{lllllll}
\hline & \multicolumn{2}{l}{ Male $(\mathrm{n}=59)$} & \multicolumn{4}{c}{ Female $(\mathrm{n}=131)$} \\
& Mean & SD & Rank & Mean & SD & Rank \\
\hline Memory & 2.78 & .63 & 6 & 2.64 & .71 & 6 \\
Cognitive & 2.98 & .64 & 4 & 2.88 & .76 & 5 \\
Compensation & 3.18 & .67 & 3 & 3.14 & .77 & 3 \\
Metacognitive & 3.34 & .71 & 1 & 3.31 & .83 & 1 \\
Affective & 2.94 & .71 & 5 & 2.97 & .87 & 4 \\
Social & 3.25 & .92 & 2 & 3.24 & .90 & 2 \\
Total & 3.06 & .55 & & 3.00 & .67 & \\
\hline
\end{tabular}

When examining individual strategies, both male and female students reported high range of frequency use for the same strategies except that male students reported additional two cognitive strategies (1. I try to talk like native English speakers. 2. I watch English language TV shows or go to movies spoken in English) and one affective strategy (I encourage myself to speak English even when I am afraid of making a mistake). Female students used one compensatory strategy which was not reported as a high frequency strategy by male learners ( $I$ make up new words if I do not know the right ones in English). Independent samples t-tests were used to examine the differences in the use of English learning strategies between male and female learners (see table 7).

Table 7 shows no significant differences between male and female learners in the use of the overall strategies. Also, there were no significant differences between male and female students in the use of the six strategies. 
Table 7. Independent Samples t-tests of the use of the six strategies by male and female students

\begin{tabular}{llll}
\hline & $\mathrm{T}$ & $\mathrm{Df}$ & Sig. (2-tailed) \\
\hline Memory & 1.26 & 125 & .21 \\
Cognitive & .96 & 131 & .34 \\
Compensatory & .31 & 128 & .76 \\
Metacognitive & .28 & 129 & .78 \\
Affective & -.30 & 136 & .77 \\
Social & .10 & 110 & .92 \\
Overall & .647 & 135 & .52 \\
\hline
\end{tabular}

Note. ${ }^{*} \mathrm{p}<0.05$

\section{Discussion}

The results of question 1 about the general patterns of English language learning strategies used by UGRU's students at the UAEU reveal that students were medium strategy users in regard to the overall strategy use. These results were consistent with results of some previous research conducted among Arab EFL learners (Abu Shmais, 2003; McMullen, 2009; Yang, 2010). However they were inconsistent with results of some other studies which reported high range of overall use of language learning strategies such as Yilmaz's (2010) study. According to Oxford (1990), a medium range of strategy use means that the strategies are sometimes, occasionally, once in a while, and now and then used. This does not reflect a consistent use of language learning strategies that can help learners become successful strategy users or better language learners.

When considering strategies separately, metacognitive strategies were the most frequently used followed by social, compensation, affective, cognitive, and memory strategies respectively. This is consistent with some studies investigating LLS (Gerami \& Baighlou, 2011; Riazi, 2007). Metacognitive strategies help learners understand and produce new language through practicing, summarizing, reasoning deductively and analyzing (Oxford, 1990). Emirati students seem to be placing great emphasis on controlling their own language learning process and progress since these strategies are used to encourage learners to overcome the new experience of learning unfamiliar grammatical structures, new words, confusing writing systems, and seemingly "non-traditional instructional approaches" (Oxford, 1990, p. 136).

Social strategies came second $(M=3.24, S D=.90)$. This result is consistent with research findings of other Arab learners (Khalil, 2005; Radwan, 2011). These strategies help learners interact, communicate, cooperate, and empathize with others to maximize learning (Oxford, 1990). In this study, the most frequently used social strategy was: "I ask English speakers to correct me when I talk" $(M=3.39, S D=1.18)$ and the least frequently used social strategy was: "I practice English with other students." $(M=2.98, S D=1.24)$. Social strategies are considered crucial to improve communication skills and interpersonal behaviors such as asking questions, asking for clarification and help, talking with native speakers, etc. (Yang, 2010). In an earlier study Yang (1996) indicated that preference for social strategies can be attributed to the learners' extensive exposure to computer, multimedia and networking technologies. Another factor might be due to the widespread of mobile technologies, Internet and social networks which are today very common among the UAE younger population.

Compensation Strategies came third $(M=3.15, S D=.74)$. This result is consistent with some research findings about Arab learners (Riazi, 2007), but inconsistent with results of other studies (McMullen, 2009; Radwan, 2011; Abu Shmais, 2003). These strategies enable learners to use the language to overcome any limitations or gaps in their linguistic knowledge (Oxford, 1990). The most frequently used strategy was: "If I can't think of an English word, I use a word or phrase that means the same" $(M=3.71, S D=1.03)$. Despite the fact that the overall mean score of compensation strategies was medium, this individual strategy showed a high frequency use. In fact, it scored the highest among the fifty strategies of the SILL. One possible explanation for the high use of this individual strategy could be attributed to the culture of the UAE where students are more concerned about communicating with the growing non-Arabic speaking population. The least frequently used strategy was: " $I$ read English without looking up every new word" $(M=2.59, S D=1.58)$. This could be attributed to the nature of instruction these students received in schools earlier.

Affective strategies ranked four $(M=2.91, S D=.73)$ This result is consistent with some research findings about Arab learners (Al-Shaboul, Asassfeh, \& Al Shboul, 2010), but it is inconsistent with some other findings from 
other studies (McMullen, 2009; Riazi, 2007; Abu Shmais, 2003; Khalil, 2005; Radwan, 2011). These strategies help learners lower their anxiety levels, increase motivation, and control their emotions (Oxford, 1990). Most of the affective strategies fell under the medium range of strategy use, except for the following strategy: "I write down my feelings in a language learning diary".

Cognitive Strategies came fifth $(M=2.91, S D=.73)$. This result is inconsistent with research findings about Arab learners (McMullen, 2009; Riazi, 2007; Abu Shmais, 2003; Khalil, 2005; Radwan, 2011; Al-Shaboul, Asassfeh, \& Al Shboul, 2010). Cognitive Strategies help learners understand and produce new language through practicing, summarizing, reasoning deductively and analyzing (Oxford, 1990). Cognitive strategies showed medium range of use except for one strategy that showed a lower range: "I read for pleasure in English". Cognitive strategies are of major importance to language learning as they include skills that require learners to use all their mental processes, such as repeating, practicing with sounds and writing systems, using formulas and patterns, recombining familiar items in new ways, practicing the new language, etc.

Memory strategies were the least preferred strategies $(M=2.69, S D=.69)$ This result is consistent with research findings about Arab learners (Al-Shaboul, Asassfeh, \& Al Shboul, 2010; Radwan, 2011;), but it is inconsistent with findings from other studies (McMullen, 2009; Riazi, 2007; Abu Shmais, 2003; Khalil, 2005). Memory strategies help learners remember, store and retrieve new information (Oxford, 1990). Six of the nine memory strategies fell under the medium range of use while three other strategies demonstrated lower strategy use. Memory strategies help students remember more effectively.

The second research question investigated the relationship between the use of language learning strategies and language proficiency levels (level one, level two and level three). The results indicate that there was no significant relationship between language learning strategy patterns and students' levels of language proficiency. One interpretation of this result might be that instruction was tailored to assist learners to pass the IELTS exam which is a prerequisite for starting taking academic courses in their colleges. Another reason might be that learners at the three levels were trained on the same set of strategies and skills. Additionally, curriculum and/or instructional materials might have been designed in an exam-oriented fashion.

The third research question investigated the relationship between male and female students' uses of language learning strategies. The results of this research question reveal no significant differences in the use of strategies between male and female students. These findings might be due to the importance of English language for both male and female Emirati learners. Both groups consider English language proficiency as an important factor in their life. Although there was no overall significant mean difference between male and female learners use of strategies, the mean scores of male learners in each of the six categories were slightly higher than those means of female learners. Both male and female students reported using metacognitive strategies the most and memory strategies the least.

When considering the use of each individual strategy, both male and female students reported almost similar higher frequency uses of strategies. However, male students reported additional two cognitive strategies (1. I try to talk like native English speakers, 2. I watch English language TV shows or go to movies spoken in English) and one affective strategy (I encourage myself to speak English even when I am afraid of making a mistake). Female students used one compensatory strategy that was not reported by male learners (I make up new words if I do not know the right ones in English). This might be attributed to cultural factors within the UAE society. Male learners might have more opportunities to communicate and interact with English language speakers outside the University.

\section{Conclusion}

The choice of language learning strategies may have a greater impact on students' attempts to acquire a second or a foreign language. Among other factors that may influence students' selections and uses of learning strategies, language proficiency level plays a major role in enabling students to choose the right strategies and use them effectively. The main purpose of this study was to examine the patterns of language learning strategies employed by male and female university students in the UAE. The study also investigated if there was any significant difference in relation to language proficiency levels and gender. An Arabic translated version of the Oxford's (1990) Strategy Inventory for Language Learning (SILL) was used for collecting the required data for this study. The results of this study reveal that UGRU's students were medium strategy users in regard to the overall strategy use. When considering strategies separately, metacognitive strategies were found to be the most frequently used followed by social, compensation, affective, cognitive, and memory strategies respectively. The findings also indicate that there was no significant relationship between language learning strategy patterns and language proficiency levels (level one, level two and level three). Furthermore, the results reveal no significant 
differences in the use of strategies between male and female students. Finally, the findings of this study have made a considerable contribution to the effort of reaching a better understanding of the overall strategies used by Emirati students to learn English at the tertiary level. The overall findings of this research have implications at different levels, namely at a decision making level, curriculum design level, materials development level and classroom instruction level.

\section{Recommendations for Further Studies}

Although this study has made significant contributions to research in the gulf region regarding the use of strategies in learning another language, more studies are still needed to look at the topic from different angles. Using multiple tools for collecting data will strengthen and consolidate the obtained results. Studies might be conducted with a larger population from different tertiary institutions using other data collection tools in addition to the SILL instrument, such as focus group or individual interviews, think aloud recall protocol, classroom observation, etc.

\section{References}

Abu Shmais,W. (2003). Language learning strategy use in Palesitne. TESL-EJ, 7(2), 1-16.

Al-Shaboul, Y. M., Asassfeh, S. M., \& Al Shboul, S. S. (2010). Strategy Use by English-Major Jordanian Undergraduates. The Australian Educational and Developmental Psychologist, 27(1), 31-40.

Chamot, A. U., Barnhardt, S., El-Dinary, P. B., \& Robbins, J. (1999). The learning strategies handbook. White Plains, NY: Addison Wesley Longman.

Cohen, A. D. (2003). The Learner's side of foreign language learning: Where do styles, strategies, and task meet? International Review of Applied Linguistics, 41(4), 279-291. (Special Issue, R. Oxford, Ed., entitled "Language Learning Styles and Strategies: New Perspectives on Theory and Research").

Dornyei, Z. ( 1990). Conceptualizing motivation in foreign language learning. Language Learning, 40, 45-79. http://dx.doi.org/10.1111/j.1467-1770.1990.tb00954.x

Douglas, S. P., \& Craig, S. C. (2007). Collaborative and Iterative Translation: An Alternative Approach to Back Translation. Journal of International Marketing, 15(1), 30-43.

Ehrman, M. E., \& Oxford, R. L. (1990). Adult learning styles and strategies in an intensive training setting. The Modem Language Journal, 74, 311-327.

Farah, \& Ridge. (2009). Challenges to Curriculum Development in the UAE. (pp. 1-8). Dubai: Dubai School of Government Policy Brief, $16 . \quad$ Retrieved from http://www.dsg.ae/en/Publication/Pdf_En/DSG\%20Policy\%20Brief\%2016\%20English.pdf

Gerami, M. H., \& Baighlou, S. M. (2011). Language Learning Strategies Used by Successful and Unsuccessful Iranian EFL Students. Procedia - Social and Behavioral Sciences, 29, 1567-1576.

Griffiths, C., \& Parr, J. M. (2001). Language learning strategies: theory and perception. ELT Journal, 55(3), 247-254.

Khalil, A. (2005). Assessment of Language Learning Strategies Used by Palestinian EFL Learners. Foreign Language Annals, 38(1), 108-117.

Littlewood, W. (2001). Students' attitudes to classroom English learning: A cross-cultural study. Language Teaching Research, 5(1), 3-28. http://dx.doi.org/10.1177/136216880100500102

McMullen, M. G. (2009). Using language learning strategies to improve the writing skills of Saudi EFL students: Will it really work? System, 37(3), 418-433.

Oxford, R. L. (1990). Langauge Learning Strategies: What every teacher should know. New York: Newbury House Publishers.

Oxford, R. L., \& Burry-Stock, J. A. (1995). Assessing language learning strategies worldwide with the ESL/EFL version of the strategy inventory for language learning (SILL). System, 23(1), 1-23.

Radwan, A. A. (2011). Effects of L2 proficiency and gender on choice of language learning strategies by university students majoring in English. Asian EFL Journal, 12(1), 115-163.

Rahimi, M., \& Riazi, A. (2005). Iranian EFL learners' pattern of language learning strategy use. Journal of Asia TEFL, 2(1), 103-129. 
Riazi, A. (2007). Language Learning Strategy Use: Perceptions of Female Arab English Majors. Foreign Language Annals, 40(3), 433-440.

The Common Educational Proficiency Assessment (CEPA) (nd.). Retrieved July 12, 2013, from ws2.mohesr.ae/napo/Details_EN.aspx?str $=$ CEPA

Wharton, G. (2000). Language learning strategy use of bilingual foreign language learners in Singapore. Language Learning, 50(2), 203-243.

Yang, M. (2010). Language Learning Strategies Of English As A Foreign Language University Students In Korea. Doctoral dissertation. ProQuest, UMI Dissertations Publishing, 2010. 3404469.

Yang, N. D. (1996). Effective Awareness-Raising in Language Learning Strategy Instruction, in R. Oxford (ed.), Language Learning Strategies around the World: Cross-Cultural Perspectives, Technical Report 13, Second Language Teaching and Curriculum Center, University of Hawaii, 205-210.

Yilmaz, C. (2010). The relationship between language learning strategies, gender, profeciency and self-efficasy beliefs: a study of ELT learners in Turkey. Procedia Social and Behavioral Sciences, 2, 683-687. http://dx.doi.org/10.1016/j.sbspro.2010.03.084

\section{Appendix A}

Arabic Version of Strategy Inventory for Language Learning (SILL)

Version 7.0 (ESL/EFL)

(C) R. Oxford, 1989

$$
\text { استبيان حول استراتيجيات تعلم اللغة اللغة الإنجليزية من الناطقين باللغات الأخرى }
$$

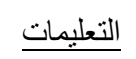

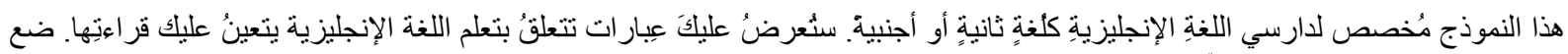

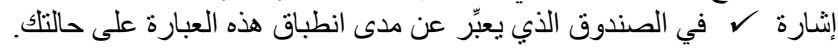

$$
\begin{aligned}
& \text { 1. ل التطبق، أو نادِر جدأ ما تنطبق على حالتي. } \\
& \text { 2. }
\end{aligned}
$$

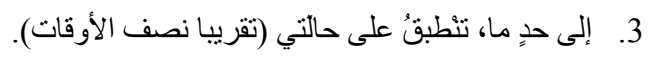

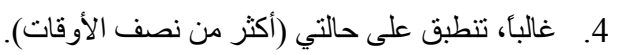

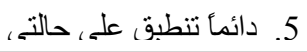

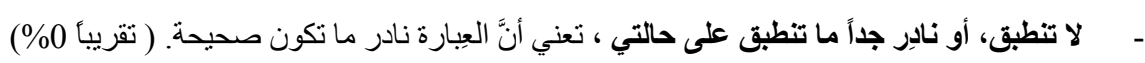

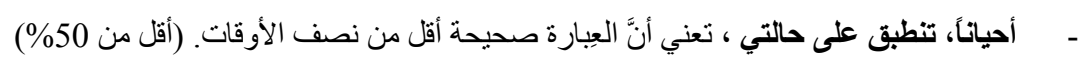

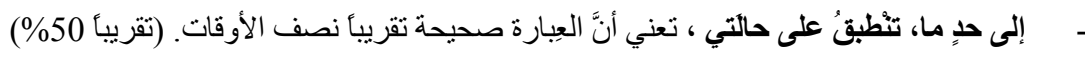

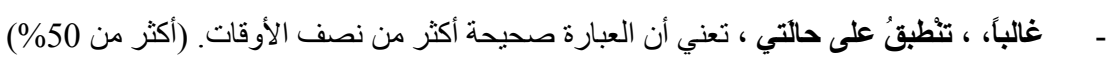

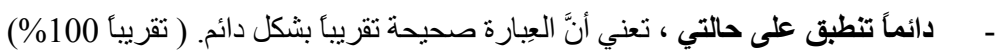

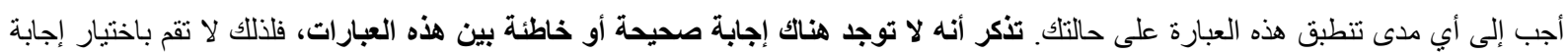

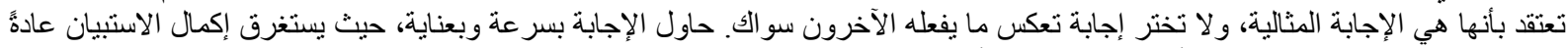

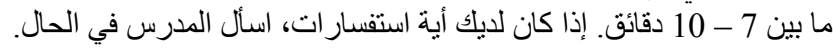




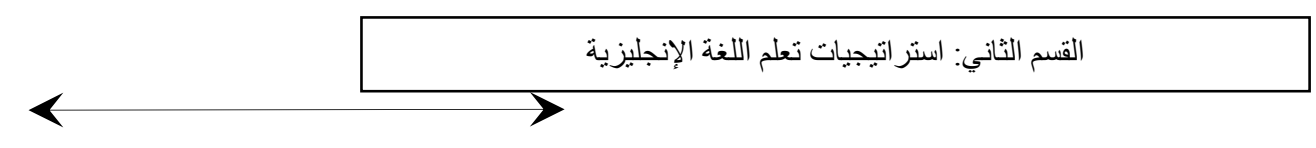

\begin{tabular}{|c|c|c|c|c|c|c|}
\hline 100 & 75 & 50 & 25 & $\% 0$ & ضع إنشارة ل حول مدى انطباق هذه العبار ات على حالتك الخاصة إثناء تعلكك اللغة الإنجليزية & \\
\hline | دائماً & 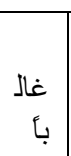 & إلى حد & نأن أحيا & نادراً تنطبق أو & الاستر اتيجيات & $ت$ \\
\hline ـ دائماً & غال & ما & نأن أحيا & | ل ا تنطبق & أفخّر في العلاقات بين ما أعرفه أصلا و الأمور الجديدة التي أنعلمها في الإنجليزية. & 1 \\
\hline | دائماً & غال & ما & نأحيا & | ل ا تنطبق & أستعملُ الكلمات الإنجليزية الجديدة في جملة كي أتذكرها & 2 \\
\hline ـ دائماً & غال & ما ل إلى حد & أحيا & | ل ا تنطبق & أربُط ما بين صوت الكلمة الإنجليزية الجديدة مع صوره أو رسمة للكلمة لتساعدني على تذكرها. & 3 \\
\hline ـ دائماً & \begin{tabular}{|c|} 
غأ \\
\end{tabular} & إلى حد & نأ & | لا تنطبق & أنذكرُ الكلمة الإنجليزية الجديدة من خلال صنع صورة ذهنية لموقف قد تستخدم فيه هذه الكلمة. & 4 \\
\hline | دائماً & 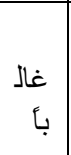 & إلى حد & نأ أحيا & | لا تنطبق & أستخدم الوقع الموسيقي لتذكر الكلمات الإنجليزية الجديدة. & 5 \\
\hline | دائماً & غال & إلى حد & نأحيا & | لا تنطبق & أستخدمُ بطاقات لكتابة الدفردات الجديدة كي أتذكر الكلمات الإنجليزية الجديدة. & 6 \\
\hline دائماً & غال & إلى حد & نأ & | لا تنطبق & أقوم بتمثيل الكلمات الإنجليزية الجديدة بشكل حركي & 7 \\
\hline دائماً & غال & إلى حد & نأحيا & | لا تنطبق & أراجع دروس اللغة الإنجليزية بكثرة. & 8 \\
\hline [ائماً & \begin{tabular}{|l} 
غال \\
\\
\end{tabular} & إلى حد & نأ & | لا تنطبق & أنذكر الكلمات أو العبارات الإنجليزية الجديدة عن طريق تذكر موقعها في الصفحة أو على النى & 9 \\
\hline | دائماً & 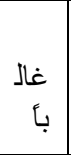 & ما & نأحيا & | ل ا تنطبق & أقوم بترديد أو كتابة الكلمات الإنجليزية الجديدة عدة مرات & 10 \\
\hline ـ دائماً & 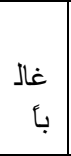 & ما & نأحيا & | لا تنطبق & |أحاول التحدث مثل الناطقين باللغة الإنجليزية & 11 \\
\hline [ائماً & 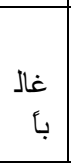 & ما & نأحيا & | ل ا تنطبق & أنترنُ على نطق أصوات اللغة الإنجليزية. & 12 \\
\hline دائما & غالا & إلى حد & 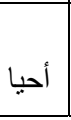 & | لا تنطبق & أستخدم الكلمات الإنجليزية التي أعرفها بطرق مختلفة. & 13 \\
\hline
\end{tabular}




\begin{tabular}{|c|c|c|c|c|c|c|}
\hline & بأ & ما & نأ & & & \\
\hline دائماً & غال & ما إلى حد & ناّ أحيا & لا تتطبق & أبادر بإجر اء محادثات باللغة الإنجليزية & 14 \\
\hline دائماً & غآ & ما إلى حد & نأَ أحيا & لا تتطبق & أثناهد البر امج التلفزيونية أو أذهب لمشاهدة الأفلام السينمائية الناطقة بالإنجليزية. & 15 \\
\hline دائماً & غآ & ما & ناً أحيا & لا تتطبق & أقر أ الكتب الإنجليزية من أجل التسلية و الترفيه. & 16 \\
\hline دائماً & غأ & ما لـى حد & نأ أحيا & لا تتطبق & أستخدم اللغة الإنجليزية في تدوين الملاحظات و الرسائل و المر اسلات و التقارير. & 17 \\
\hline دائماً & غآ & ما & نأ أحيا & لا تتطبق & عند قر اعتي لنص باللغة الإنجليزية، أقر أه للمرة الأولى بسر عة، و الثانية بتمهل و عناية. & 18 \\
\hline دائماً & غأ & ما لـى حد & نأ & لا تتطبق & أبحث عن كلمات في اللغة العربية مماثلة لتلك الكلمات الجديدة التي تعلمتها في اللغة الإنجليزية. & 19 \\
\hline دائماً & غأ & ما لـى حد & نأ أحبا & لا تتطبق & أحاول البحث عن أنماطٍ (قو اعد) في اللغة الإنجليزية. & 20 \\
\hline دائماً & غال & ما لى حد & نأ & لا تتطبق & أجد معنى الكلمة الإنجليزية عن طريق تقسيمها إلى مقاطع بسهل عليَّ فهمها. & 21 \\
\hline دائماً & غال & ما لـى حد & نأ أحيا & لا تتطبق & أحاول تجنب الترجمة الحرفية. & 22 \\
\hline دائماً & غال & ما لـى حد & ناّ أحيا & لا تتطبق & أقوم بإعداد ملخصات للمعلومات الجديدة التي أسمعها أو أقر أها باللغة الإنجليزية & 23 \\
\hline دائماً & غآ & ما لـى حد & نأ أحيا & لا تنطبق & أحاول فهم الكلمات الإنجليزية التي لا أعرفها عن طريق تخمين معانيها. & 24 \\
\hline دائماً & غآ & ما لـى حد & نأ & لا تتطبق & عندما لا أجد الكلمات المناسبة إثناء التحدث باللغة الإنجليزية أستعيض عنها بالإشارة. & 25 \\
\hline دائماً & غأ & إلى حد & نأ أحيا & لا تنطبق & أقوم باستخدام كلمات جديدة تعبر عن المعنى المر اد إن كنت لا أعرف الكلمات الصحيحة لذلك في & 26 \\
\hline
\end{tabular}


(C) R. Oxford, 1989

\begin{tabular}{|c|c|c|c|c|c|c|}
\hline 100 & 75 & 50 & 25 & $\% 0$ & لحول مدى انطباق هذه العبار ات على حالتك الخاصة إثناء تعلكك اللغة الإنجليزية & ب إثـار \\
\hline دائماً & غالّ & |إلى & أحياناً & تأ & الاستر اتيجيات & ت \\
\hline دائماً & غال & 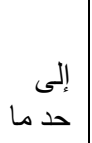 & أحياناً & 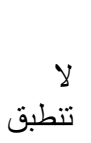 & أقوم بالقر اءة باللغة الإنجليزية دون البحث عن معاني جميع الكلمات الجديدة. & 27 \\
\hline دائماً & غأل & 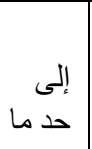 & أحياناً & 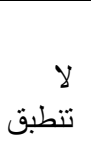 & إثناء التحدث باللغة الإنجليزية، أحاول التنبؤ بما سيتحدث به الطرف الآخر. & 28 \\
\hline دائماً & غآ & 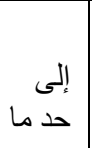 & أحياناً & 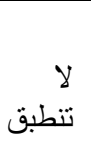 & إذا لم استطع تذكر كلمة إنجليزية ما، أحاول استخدام كلمة أو عبارة قريبة لها في المعنى. & 29 \\
\hline دائماً & غال & 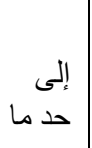 & أحياناً & 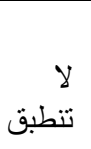 & أحاول قدر الإمكان إيجاد طرق عدة لاستخدام لغتي الإنجليزية. & 30 \\
\hline دائماً & غال & 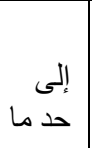 & أحياناً & 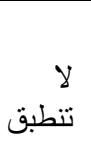 & أحاول إدر الك أخطائي في اللغة الإنجليزية، كي أنداركها، وأحسِّنَ من مستواي. & 31 \\
\hline دائماً & غال & 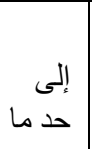 & أحياناً & 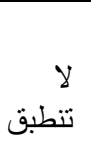 & أصغي بانتباه لمن يتحدث باللغة الإنجليزية. & 32 \\
\hline دائماً & غآ & 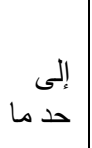 & أحياناً & 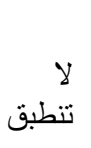 & أحاول أن أجد ما يجعلني متعلماً أفضل للغة الإنجليزية. & 33 \\
\hline دائماً & غال & 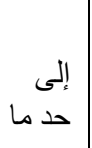 & أحياناً & 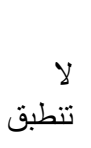 & أعد برنامجي الدر اسي بحيث يتوفر لاي الوقت اللازم لدر اسة اللغة الإنجليزية. & 34 \\
\hline دائماً & غال & 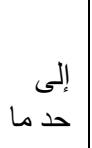 & أحياناً & 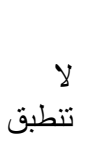 & أبحث عن أشخاص يمكنني التحدث إليهم باللغة الإنجليزية. & 35 \\
\hline دائماً & غال & إلى ما & أحياناً & تنطبق & أبحث عن فرص للقر اءة باللغة الإنجليزية قدر الإمكان. & 36 \\
\hline دائماً & غاً & إلى ما & أحياناً & تنطبق & لدي أهداف و اضحة لتحسين مهار اتي في اللغة الإنجليزية. & 37 \\
\hline دائماً & غال & إلى ما & أحياناً & تنطبق & أفكر بالتقدم الذي أحرزه في تعلم اللغة الإنجليزية. & 38 \\
\hline & غال & إلى & & ע & أحاول تهدئة نفسي كلما شعرت بالخوف من استخدام اللغة الإنجليزية. & 39 \\
\hline
\end{tabular}




\begin{tabular}{|c|c|c|c|c|c|c|}
\hline دائما & ب & 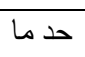 & أحيانًا & تنطبق & & \\
\hline دائماً & 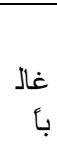 & إلى ما & 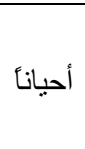 & ت التطبق & أثنجع نفسي على التحدث بالإنجليزية حتى لو كنت خائفأ من أن أخطى. & 40 \\
\hline دائماً & 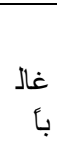 & إلى ما & أحيانًا & 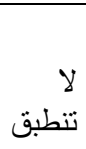 & أكافئ نفسي كلما أصبحت أفضل في اللغة الإنجليزية. & 41 \\
\hline دائماً & 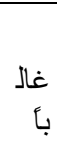 & إلى ما & أحيانًا & تنطبق & أدرك إن أصابني التوتر خلال دراستي أو استخدامي للغة الإنجليزية. & 42 \\
\hline دائماً & 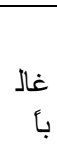 & إلى ما & أحيانًا & تلنطبق & أدون مشاعري في مفكرة خاصة بتعلم اللغة الإنجليزية. & 43 \\
\hline دائماً & 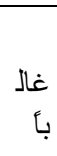 & إلى ما & أحياناً & 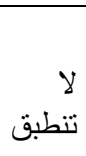 & أنحدث إلى شخص آخر عن شعوري عندما أنعلم اللغة الإنجليزية. & 44 \\
\hline دائماً & 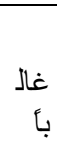 & إلى ما & أحيانأ & 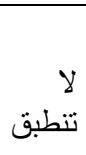 & ثانية. لم أفهم بعض ما يُقال باللغة الإنجليزية، أطلب من المتحدث أن يبطء في الحديث أو أن يعيد & 45 \\
\hline دائماً & غأ غال & إلى ما & أحيانأ & تلنطبق & أطلب من الناطقين باللغة الإنجليزية تصحيحي عندما أنحدث. & 46 \\
\hline دائماً & غأ غال & إلى ما & أحيانأ & 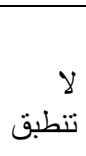 & أمارس اللغة الإنجليزية مع طلاب الآخرين. & 47 \\
\hline دائماً & غأ غال & إلى ما & أحيانأ & 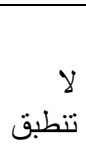 & أطلب السساعدة من الناطقين باللغة الإنجليزية. & 48 \\
\hline دائماً & غأ غال & إلى ما & أحياناً & 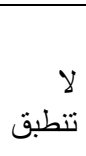 & أطرح الأسئلة باللغة الإنجليزية. & 49 \\
\hline دائماً & غأ غال & إلى ما & أحيانأ & تلنطبق & أحاول أن أتعلم عن ثقافة الناطقين باللغة الإنجليزية. & 50 \\
\hline
\end{tabular}




\section{Appendix B}

Background Information Questionnaire

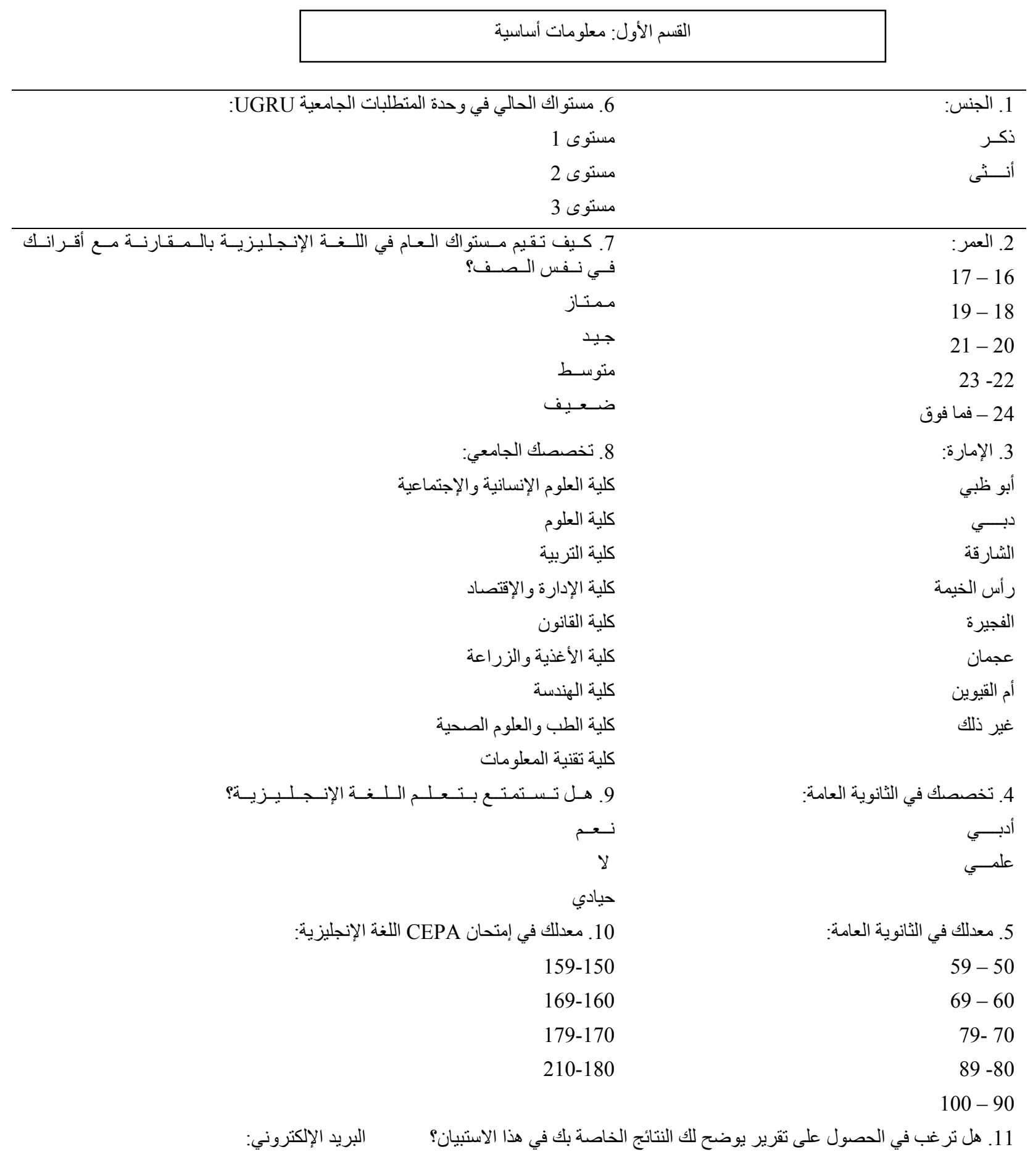

\section{Copyrights}

Copyright for this article is retained by the author(s), with first publication rights granted to the journal.

This is an open-access article distributed under the terms and conditions of the Creative Commons Attribution license (http://creativecommons.org/licenses/by/3.0/). 